and along the south coast, a wave of less height was experienced

"The Meda, on our passage down from Ashburton River (when distant from 50 to 100 miles off the west coast of Australia, and about rooo miles south-south-east of Sunda Strait), was visited by a shower of volcanic dust (in appearance like prepared "fuller's earth"), which fell some time between sunset of August 30 and sunrise of August $3 \mathrm{I}$, the wind being on-shore at the time.

"If the dust were associated with the disturbances in Sunda Strait of Angust 27 and 28, it must have travelled I050 miles in three days."

\section{BICENTENARY OF BACTERIA}

$[\mathrm{W}$ $\mathrm{E}$ have received the two following communications on this subject:-ED.]

AT the present time, when so many anniversaries of great men and great events are celebrated, it seems opportune to remember that exactly two centuries have passed since a discovery of the greatest consequence was made in the Netherlands. In a letter dated September 14, I683, from Delft, to Francis Aston, F.R.S., of London, Antony van Leeuwenhoek gives notice to the Royal Society that with the aid of his microscope he has discovered in the white substance adhering to his teeth very little animals moving in a very lively fashion (" animalcula admodum exigua jucundissimo modo sese moventia." "Arcana naturæ detecta," Delft, I695: "Experimenta et Contemplationes," p. 42). They were the first Bacteria the human, ye ever saw. Among them Leeuwenhoek distinguishes several species, the descriptions and drawings of which are so correct that we may easily recognise them. The rods, with rapid movement penetrating the water like fishes, are Bacilli; the smaller ones rotating on the top are Bacterium; one undulating species is Vibrio rugula; the parallel threads of unequal length but of equal breadth are Leptothrix buccalis; though motionless, they belong to the moving Bacilli. Leeuwenhoek wonders how, notwithstanding the scrupulous care with which he cleans his teeth, there could live more animalculæe in his mouth than men in all the provinces of the States-General. Some years later, not perceiving again the movements of the Bacteria between his teeth, he supposes he had killed them by taking hot coffee at breakfast ; but very soon he discovers anew the old species, and the new drawings of Bacillus and Leptothrix which he sends to the Royal Society in the middle of September, 1692 (l.c., p. 336) are still more accurate than those of 1683 . They have not been surpassed till within the last ten years. It deserves our highest admiration that the first discoverer of the invisible world cunld already reach a limit which bas never been overstepped, though the members of the Royal Society, when considering two hundred years ago the curious communications of the philosopher of Delft, may have scarcely foreseen that his astonishing discovery had opened to science a new path which only in our own days has led to the most important revelations about fermentation and disease.

Breslau, November 27

FERDINAND COHN

IT cannot be a matter of indifference to English men of science, and especially to the Fellows of the Royal Society, that the bicentenary of the discovery of those immensely important agents of putrefaction, fermentation, and disease, the Bacteria, is at hand.

It was to the Royal Society of London that Antony van Leeuwenhoek communicated his discovery, and we may be sure that neither he nor the Royal Society of that day anticipated the extraordinary interest which would attach itself in two centuries' time to the organisms dis. covered by the patient and accurate student of minute life.
Leeuwenhoek's "discovery" is a remarkable example of that unexpected giving of rich gifts to future generations of men which marks the progress of scientific research in all its branches. It is for the Royal Society to devise some means of celebrating this bicentenary in such a fashion as to use the great interest and even fascination which Bacteria have at this moment for the English public, so as to excite sympathy with pure and unremunerative scientific research. Antony van Leeuwenhoek is the type of the single-minded student of living structures. The investigation of the properties and life-history of Bacteria, although commenced by him two hundred years ago, is still in its infancy. Schwann, Pasteur, Lister, Cohn, Nägeli, and Koch have brought us within the las! fifty years far beyond Leeuwenhoek's first discovery, but a hundred such men are needed to carry on the work of discovery. Who will employ them? Are we to wait two centuries more for knowledge about Bacteria which lies, as it were, ready to our hands, waiting to be picked up? knowledge which will probably save many thousands of lives annually-if we may judge by the results already attained by the discovery of the relation of Bacteria to the sup. puration of wounds and to the production of diseases.

The Royal Society could not better celebrate the bicentenary of its Dutch correspondent's discovery than by taking steps to urge on the English Government the expenditure of ample funds upon a new and vigorous prosecution of the study of the relations of Bacteria to disease, in fact upon the foundation of a national laboratory of hygiene.

L.

\section{THE UPPER CURRENTS OF TIIE ATMOSPHERE}

$A$ LL winds are caused directly by differences of atmospheric pressure, just in the same way that the flow of rivers is caused by differences of level ; the motion of the air and that of the water being equally referable to gravitation. The wind blows from a reg.on of higher towards a region of lower pressure, or from where there is a surplus to where there is a deficiency of air. Every isobaric map, showing the distribution of the mass of the atmosphere over any portion of the earth's surface, indicates a disturbance more or less considerable of atmospheric equilibrium, together with general movements of the atmosphere from regions of high pressure towards and in upon low-pressure areas. All observation shows, further, that the prevailing winds of any region at any season are merely the expression of the atmospheric movements which result from the disturbance of the equilibrium of the atmosphere shown by the isobaric maps as prevailing at that season and over that region. All observation shows, in a manner equally clear and uniform, that the wind does not blow directly from the region of high towards that of low pressure, but that, in the northern hemisphere, the region of lowest pressure is to the left hand of the direction towards which the wind blows, and in the southern hemisphere to the right of it. This direction of the wind in respect of the distribution of the pressure is known as Buys Ballot's Law of the Winds, according to which the angle formed by a line drawn to the centre of lowest pressure from the observer's position, and a line drawn in the direction of the wind is not a right angle, but an angle of from $60^{\circ}$ to $80^{\circ}$. This law absolutely holds good for all heights up to the greatest height in the atmosphere at which there are a sufficient number of stations for drawing the isobarics for that height; and the proof from the whole field of observation is so uniform and complete that it cannot admit of any reasonable doubt that the same law holds good for all heights of the atmosphere.

In low latitudes, at great elevations, atmospheric pressure is greater than it is in higher latitudes at the same height, for the obvious reason that owing to the lower temperature 
of higher latitudes the air is more condensed in the lower strata, thus leaving a less pressure of air at great heights. It f sllows that the steepest barometric gradients for the upper currents of the atmosphere will be formed during the coldest months of the year. At Bogota, 8727 feet in height, where the temperature is nearly uniform throughout the year, the mean pressure for January and July are 22.048 and 22.058 inches. On the other hand, at Mount Washington, 6285 feet high, where the January and July mean temperatures are $6^{\circ} \cdot 4$ and $48^{\circ} \cdot 2$, the mean pressures for the same months are 23.392 and 23.875 inches. Similarly at Pike's Peak, I4, I5 I feet high, the mean temperatures are $3^{\circ} \cdot \mathrm{I}$, and $39^{\circ} .7$, and the mean pressures 17.493 and 18.069 inches; and since the sea-level pressures in the region of Pike's Peak are nearly 0.500 inch higher in January than in July, it follows that the lowering of the pressure on the top of Pike's Peak due to the lower temperature of January is upwards of 1.000 inch. From the greatly steeper barometric gradients thus formed for upper currents during the cold months of the year from equatorial to polar regions, these currents attain their maximum strength in winter and converge upon those regions of the earth where the mean temperature is lowest

As is now well known, atmospheric pressure in summer is lowest in the central regions of the continents of Asia, Africa, and America ; and highest in the Atlantic between Africa and the United States, and in the Pacific between the United States and Japan, the absolutely lowest being in Asia, where temperature is relatively highest with respect to the regions immediately surrounding, and absolutely lowest in the Atlantic, which is most completely surrounded with highly-heated continental lands. Again, in winter the lowest atmospheric pressures are found in the north of the Atlantic and Pacific Oceans, where temperature is relatively highest, latitude for latitude ; and the highest pressures towards the centres of the continents, some distance to southward of the regions where at this season abnormally low temperatures are lowest.

The causes which bring about an unequal distribution of the mass of the atmosphere are the temperature and the moisture considered with respect to the geographical distribution of land and water. Owing to the different relations of land and water to temperature, the summer temperature of continents much exceeds that of the ocean in the same latitudes; and hence results the abnormally high temperature of the interior of Asia, Africa, America, and Australia during their respective summers, in consequence of which the air becoming specifically lighter ascends in enormous columns thousands of miles in diameter. Winds from the ocean set in all round to take the place of the air thus removed, raising the rainfall to the annual maximum, and still further diminishing the atmospheric pressure. On the other hand, since in winter the temperature of the continents and their atmosphere falls abnormally low, the air becomes more condensed in the lower strata, and pressure is thereby diminished in the upper regions over the continents. Upper currents set in all round upon the continents, and thus the sea-level pressures become still further increased. Hence the absolutely highest mean pressure occurring anywhere on the globe at any season, about $30^{\circ} 500$ inches, occurs in Africa in the depth of winter.

Now observation conclusively proves that from the region of high pressure in the interior of Asia in winter, from the region of high pressure in the Atlantic in summer, and from all other regions of high pressure, the winds blow outwards in all directions; and that towards the region of low pressure in Asia in summer, towards the region of low pressure in the north of the Atlantic in winter, and towards all other regions of low pressure, whenever and wherever they occur, the winds blow in an in-moving spiral course.

Since enorm ous masses of air are in this way poured into the region where pressure is low without increasing that pressure, and enormous masses of air flow out of the region where pressure is high without diminishing that presiure, it is simply a neces,ary inference to conclude that the masses of air poured all round into the region of low normal pressure do not accumulate over that region, but must somehow escape away into other regions; and that the masses of air which flow outwards on all sides from the region of high normal prejsure must have their place taken by fresh accessions of air poured in from above. Keeping in view the law of the barometric gradient as applicable to all heights of the atmosphere, it is evident that the ascending current from a low-pressure area, the air composing which is relatively warm and moist, will continue its ascent till a height is reached at which the pressure of the air of the current equals or just falls short of the pressure over the surrounding regions at that high level. On reaching this height, the air, being no longer buoyed up by a greater specific levity than that of the surrounding air, ceases to ascend, and thereafter spreads itself horizontally as upper currents towards tho se regions which offer the least resistance to it. The overflow of the upper currents is thus in the direction of those regions where pressure at the time is least, and this again we have seen to be towards and over that resion or those regions the air of which in the lower strata of the atmosphere is colder and drier than that of surrounding regions.

The broad conclusion is this: the winds on the surface of the globe are indicated by the isobaric lines showing the distribution of the mass of the earth's atmosphere near the surface, the direction of the wind being from regions where pressure is high towards regions where pressure is low, in accordance with Buys Ballot's law. On the other hand, the low-pressure regions, such as the belt of calms in equatorial regions, the interior of Asia in summer, and the north of the Atlantic and Pacific in winter, with their ascending currents, and relatively higher pressure at great heights as compared with surrounding regions, point out the sources or fountains whence the upper currents flow. From these sources the upper currents spread themselves and flow towards and over those parts of the earth where pressure is relatively low. These directions are, speaking generally, from equatorial to polar regions; but more particularly towards and over those more restricted regions where in the lower strata of the atmosphere the air is colder and drier than in neighbouring recions, such as the Atlantic between the United States and Africa in summer, and Central Asia in winter.

This view of the general movements of the upper currents of the atmosphere is in accordance with the observations which have been made in different parts of the globe on the motions of the cirrus cloud, and with observations of the directions in which ashes from volcanoes have been carried by these upper currenti. In further corroboration of the same views, reference may be made to the researches made in recent years, particularly by Prof. Hildebrandsion and Clement Ley, into the upper currents of the atmosphere, based on observations of the movements of the cirrus cloud in their relation to the cyclones and anticyclones of north-western Europe.

An important bearing of cyclonic and anticyclonic areas on the distribution of temperature may be here referred to. The temperature is abnormally raised on the east side of cyclonic areas and abnormally depressed on their west sides; but, on the other hand, temperature is abnormally raised on the west sides of anticyclonic areas, and depressed on their east sides-the directions being reversed in the southern hemisphere. ${ }^{1}$ Since the temperature is lower in the rear than in the front of a cyclone, it follows that, relatively to the sea-level pressures, pressure will be lower in the upper regions in the rear of a cyclone than in front of it, a result which the Ben Nevis observa-

" See "Reviews of Weat'ier Mups of the JUnited States," Nature, 'vols $x x i$, xxii., and xxiii. 
tions strongly confirm. Hence relatively warmer and moister upper currents will flow backward over the colder and drier air immediately in the rear of the centres of cyclones; and upper currents also presenting contrasts of temperature and vapour will overlap the outskirts of anticyclones. These considerations suggest how very diverse interpretations of the movements of the cirrus cloud in their relation to cyclones and anticylones have originated, and may also indicate lines of research into some of the more striking optical scenic displays of the atmosphere.

\section{ELECTRIC SHADOWS}

THE brilliant researches of Crookes upon the electric discharges in highly attenuated vacua, which some four years ago culminated in the discovery of the phenomena of "radiant matter," revealed, amongst other singular and curious effects, the existence of electric shadows. In the tubes employed by Crookes, wherein the rarefaction had been carried to millionths of the normal air pressure, objects cut out in sheets of metal or other good conductors of electricity were found to cast shadows against the glimmering surfaces of the glass

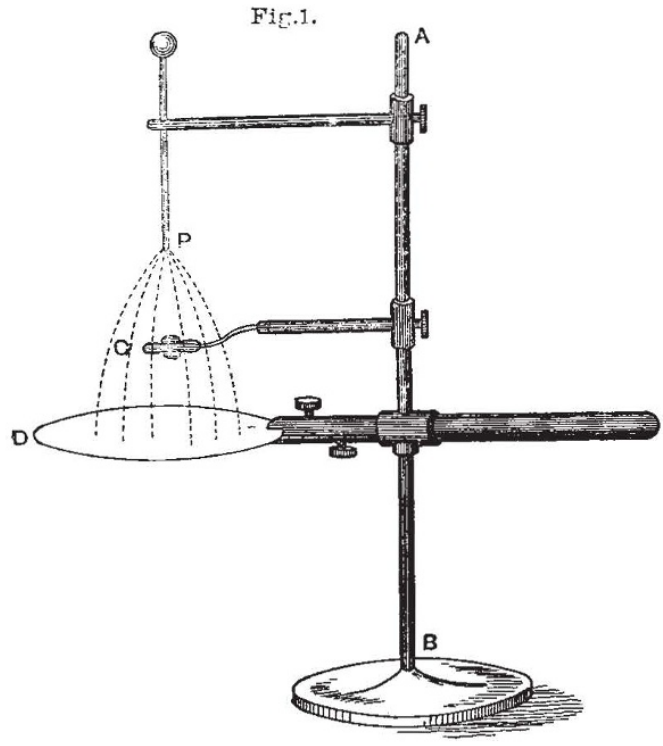

when interposed in the path of the discharge. The deflection of these shadows by the magnet was also observed by Crookes. About eighteen months afterwards some analogous phenomena were observed and described by Prof. W. Holtz of Berlin; the main difference between the phenomena observed by Crookes and by Holtz being that in the experiments of the latter the shadows were obtained at the ordinary pressure of the air by means of the discharge from a Holtz's influence machine. Of these researches some account was given at the time in NATURE (vol. xxiv. p. 130) by the writer of this article. It will be sufficient here to recall the more salient points. In the place of the usual discharging knobs of the Holtz machine were fixed a wooden disk covered with silk on the one side, and a metallic point on the other. The discharge from the latter causes the surface of the former to assume a faint, phosphorescent glow, visible only in complete darkness; and on this faintly illuminated surface shadows were cast when conducting bodies-such, for example, as crosses or rings cut from thin brass or foil, strips of damp cardboard, wires, and other similar objects. It was also noticed by Holtz that these shadowfigures could be temporarily fixed by dusting upon them some fine powder, such as lycopodium. In preparing the notice of these researches for NATURE in I88I, I made the following remark:- "These dust-figures have an obvious relation with those obtained by Wiedemann from the discharge of Leyden jars through a pointed conductor against the surfaces of various bodies. It would be interesting to ascertain whether by this process also shadow-figures can be produced." The suggestion then thrown out has not been lost, for during the current year a memoir has appeared on the subject of electric shadows from the pen of Prof. Augusto Righi, of Padua, giving

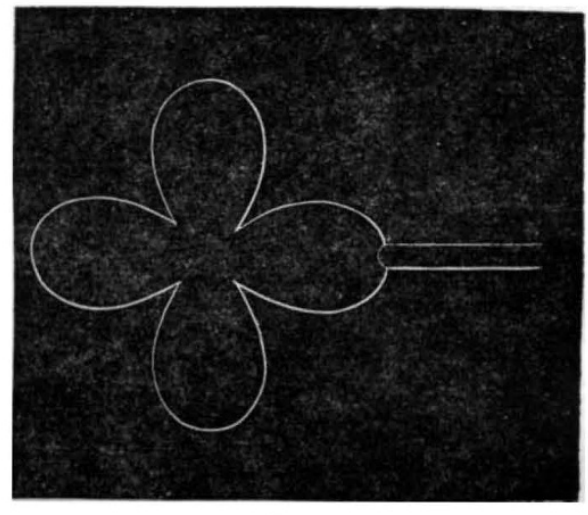

FIG. 2.

the results of an investigation of shadows produced by this very method. I propose to give here a résumé of the phenomena observed by Righi.

Righi discusses in an introductory way the suggestion of Crookes as to the relation between the length of the mean free path of the molecules and the distance to which the "radiant" discharge can be traced from the electrode. He observes that even in cases where the mean free path (as determined by the temperature of the

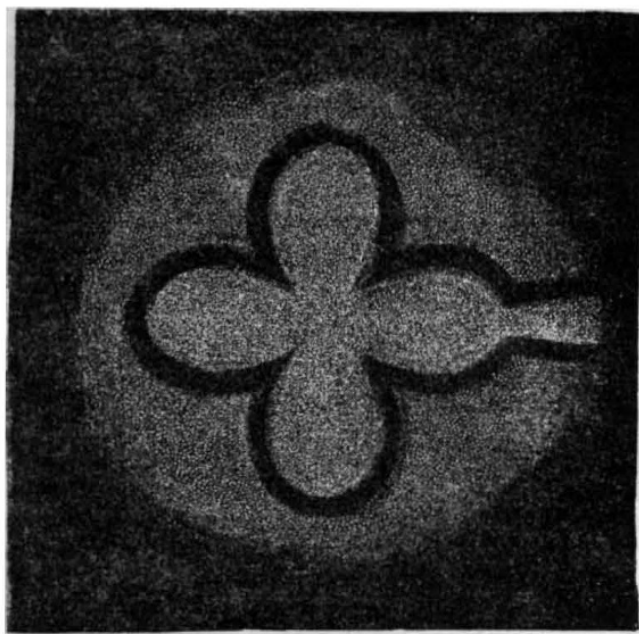

FIG. 3.

gas) be very short, as in air at ordinary pressure, the motion of the gaseous molecules as a whole may yet be in nearly straight lines of considerable length, owing to the fact that the electric force in the space where discharge is taking place will necessarily tend to urge an electrified molecule along the lines of electric force, and will act in the same direction whether the charge on any single molecule remain upon it or whether it be shared with other molecules against which it may impinge in its 